\title{
Front Matter: Volume 9565
}

, "Front Matter: Volume 9565," Proc. SPIE 9565, Liquid Crystals XIX, 956501 (20 October 2015); doi: 10.1117/12.2218465

SPIE Event: SPIE Organic Photonics + Electronics, 2015, San Diego, California, United States 


\section{PROCEEDINGS OF SPIE}

\section{Liquid Crystals XIX}

\section{Iam Choon Khoo}

Editor

9-10 August 2015

San Diego, California, United States

Sponsored and Published by

SPIE

Volume 9565

Proceedings of SPIE 0277-786X, V. 9565

SPIE is an international society advancing an interdisciplinary approach to the science and application of light.

Liquid Crystals XIX, edited by lam Choon Khoo, Proc. of SPIE Vol. 9565, 956501

(c) 2015 SPIE - CCC code: 0277-786X/15/\$18 - doi: 10.1117/12.2218465

Proc. of SPIE Vol. 9565 956501-1 Downloaded From: https://www.spiedigitallibrary.org/conference-proceedings-of-spie on 26 Apr 2023
Terms of Use: https://www.spiedigitallibrary.org/terms-of-use 
The papers in this volume were part of the technical conference cited on the cover and title page. Papers were selected and subject to review by the editors and conference program committee. Some conference presentations may not be available for publication. Additional papers and presentation recordings may be available online in the SPIE Digital Library at SPIEDigitallibrary.org.

The papers reflect the work and thoughts of the authors and are published herein as submitted. The publisher is not responsible for the validity of the information or for any outcomes resulting from reliance thereon.

Please use the following format to cite material from these proceedings:

Author(s), "Title of Paper," in Liquid Crystals XIX, edited by lam Choon Khoo, Proceedings of SPIE Vol. 9565 (SPIE, Bellingham, WA, 2015) Six-digit Article CID Number.

ISSN: 0277-786X

ISSN: 1996-756X (electronic)

ISBN: 9781628417319

Published by

SPIE

P.O. Box 10, Bellingham, Washington 98227-0010 USA

Telephone +1 3606763290 (Pacific Time) · Fax +1 3606471445

SPIE.org

Copyright (C) 2015, Society of Photo-Optical Instrumentation Engineers.

Copying of material in this book for internal or personal use, or for the internal or personal use of specific clients, beyond the fair use provisions granted by the U.S. Copyright Law is authorized by SPIE subject to payment of copying fees. The Transactional Reporting Service base fee for this volume is $\$ 18.00$ per article (or portion thereof), which should be paid directly to the Copyright Clearance Center (CCC), 222 Rosewood Drive, Danvers, MA 01923. Payment may also be made electronically through CCC Online at copyright.com. Other copying for republication, resale, advertising or promotion, or any form of systematic or multiple reproduction of any material in this book is prohibited except with permission in writing from the publisher. The CCC fee code is 0277-786X/15/\$18.00.

Printed in the United States of America.

Publication of record for individual papers is online in the SPIE Digital Library.

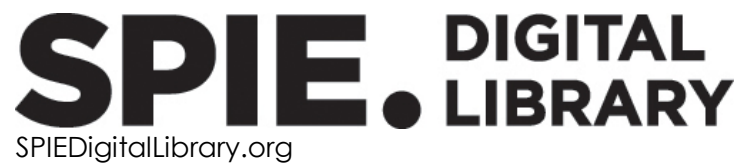

Paper Numbering: Proceedings of SPIE follow an e-First publication model. A unique citation identifier (CID) number is assigned to each article at the time of publication. Utilization of CIDs allows articles to be fully citable as soon as they are published online, and connects the same identifier to all online and print versions of the publication. SPIE uses a six-digit CID article numbering system structured as follows:

- The first four digits correspond to the SPIE volume number

- The last two digits indicate publication order within the volume using a Base 36 numbering system employing both numerals and letters. These two-number sets start with 00, 01, 02, 03, 04 , 05, 06, 07, 08, 09, OA, OB ... 0Z, followed by 10-1Z, 20-2Z, etc. The CID Number appears on each page of the manuscript. 


\title{
Contents
}

\author{
$\checkmark$ Authors \\ vii Conference Committee
}

NOVEL PHOTONIC MATERIALS AND PROCESSES

956503 Liquid crystal based adaptive holography for optical sensing applications (Invited Paper) [9565-3]

956504 Light-induced deformation of liquid crystalline polymer networks containing azobenzene chromophores (Invited Paper) [9565-4]

OPTICAL CONTROL, MANIPULATION, AND MODULATION

$95650 \mathrm{C}$ Liquid crystals under the spotlight: light based measurements of electrical and flow properties of liquid crystals (Invited Paper) [9565-12]

9565 OE Photoalignment control: self-focusing effect in hybrid- and homeotropic-aligned dye-doped polymer-stabilized liquid crystals (Invited Paper) [9565-14]

9565 OG Strengthened nonlinearity in liquid crystal panel with ZnSe aligning layers due to surface charge accumulation [9565-16]

NOVEL MATERIALS, PHENOMENA, AND APPLICATIONS

9565 ol Structural dynamics in azobenzene liquid crystal polymer films studied by microscopic time-resolved technique (Invited Paper) [9565-18]

9565 0J Thermoelectricity in liquid crystals (Invited Paper) [9565-19]

9565 OK An optical system adopting liquid crystals with electrical tunability of wavelength and energy density for low level light therapy [9565-20]

$95650 \mathrm{~L}$ Programmable lattices of optical vortices in nematic liquid crystal (Invited Paper) [9565-21]

ADVANCED PHOTONIC APPLICATIONS

9565 OM Recent advances in IR liquid crystal spatial light modulators (Keynote Paper) [9565-22] 
9565 OT Computational chemistry modeling and design of photoswitchable alignment materials for optically addressable liquid crystal devices (Invited Paper) [9565-29]

$95650 \mathrm{~V}$ Asymmetrical phase difference distribution properties of a liquid-crystal micro-lens array with tetragonally-patterned electrodes [9565-31]

\section{COMPLEX OPTICAL AND MATERIAL PROCESSES}

9565 OY Digital confocal microscopy through a multimode fiber (Invited Paper) [9565-34]

956510 Liquid-crystal-based biosensing beyond texture observations (Invited Paper) [9565-36]

\section{ADVANCED MATERIALS AND PHOTONIC APPLICATIONS}

956512 Thin waveplate lenses: new generation in optics (Keynote Paper) [9565-38]

956513 One- and two-dimensional liquid crystal structures for lasing applications (Invited Paper) [9565-39]

956516 Tunable Bragg extraction of light in photonic quasi crystals: dispersed liquid crystalline metamaterials (Invited Paper) [9565-42]

\section{POSTER SESSION}

956517 Analysis of selective reflection spectrum in cholesteric liquid crystal cells for solar-ray controller [9565-43]

956519 Multifocal liquid-crystal-lens properties with an additional ring-electrodes [9565-45]

$95651 \mathrm{~A}$ Three-dimensional imaging system by using a low-voltage-driving LC lens with a tunable focal length [9565-46]

9565 1B Bragg diffraction for normal and obliquely circularly polarized light due a new chiral mixture [9565-47]

9565 1C An optical image stabilization using a droplet manipulation on a liquid crystal and polymer composite film [9565-48]

9565 1D Thermodielectric effect in dual-frequency cholesteric liquid crystals [9565-49] 
Proc. of SPIE Vol. $9565956501-6$

Downloaded From: https://www.spiedigitallibrary.org/conference-proceedings-of-spie on 26 Apr 2023 Terms of Use: https://www.spiedigitallibrary.org/terms-of-use 


\title{
Conference Committee
}

\author{
Symposium Chair
}

Zakya H. Kafafi, Lehigh University (United States)

Conference Chair

Iam Choon Khoo, The Pennsylvania State University (United States)

Conference Program Committee

Timothy J. Bunning, Air Force Research Laboratory (United States)

Shaw-Horng Chen, University of Rochester (United States)

Neil Collings, Two Trees Photonics Ltd. (United Kingdom)

Jean-Pierre Huignard, Jphopto (France)

Tomiki Ikeda, Chuo University (Japan)

Oleg D. Lavrentovich, Kent State University (United States)

Francesco Simoni, Università Politecnica delle Marche (Italy)

David M. Walba, University of Colorado at Boulder (United States)

\section{Session Chairs}

1 Novel Photonic Materials and Processes

Iam Choon Khoo, The Pennsylvania State University (United States)

2 Electro-Optical Processes

Oleg D. Lavrentovich, Kent State University (United States)

3 Optical Control, Manipulation, and Modulation

David M. Walba, University of Colorado at Boulder (United States)

4 Novel Materials, Phenomena, and Applications

Iam Choon Khoo, The Pennsylvania State University (United States)

5 Advanced Photonic Applications

Kenneth L. Marshall, University of Rochester (United States)

6 Novel Optical and Material Processes

Nelson V. Tabiryan, BEAM Engineering for Advanced Measurements Company (United States) 
7 Complex Optical and Material Processes

Tsung-Hsien Lin, National Sun Yat-Sen University (Taiwan)

8 Advanced Materials and Photonic Applications

Iam Choon Khoo, The Pennsylvania State University (United States) 